\title{
Population Migration Flows in European Union: Economic Factors and Perspective Statistical Trends
}

\author{
Ričardas Mileris \\ Kaunas University of Technology, Lithuania \\ ricardas.mileris@ktu.lt
}

\begin{abstract}
The economic openness of European Union (E ) countries causes the constant international migration of the inhabitants inside the $\mathrm{EU}$ and beyond its borders. This research revealed the international migration flows of $\mathrm{EU}$ highlighting the depopulation problems of some EU countries interrelating them with the economic factors of international migration. Analysing the current statistical trends, the projections of population changes were extrapolated in migrants attracting and depopulating EU countries. The statistical probabilities to reduce the emigration were calculated for the most depopulating EU countries.
\end{abstract}

Key Words: European Union, international migration, population, statistical forecasts

JEL Classification: F47, F 62, J11

https://doi.org/10.26493/1854-6935.17.163-188

\section{Introduction}

The international migration flows in European Union are growing what means the increasing mobility of its inhabitants. The aggregated emigration of EU-28 countries in 2005 was 1.6 million while in 2016 this indicator increased to 3.0 million inhabitants. The aggregated immigration indicators during this period were 2.6 and 4.3 million persons accordingly. The human capital theory is based on suggestion that inhabitants migrate if the potential growth of earnings exceed migration costs (Foged 2016). The international migration of economic migrants can be temporary which is related to income increase and remittances sending to the country of origin, or permanent settlement of families that migrate when the total gains to the household outweigh financial and non-financial migration costs.

This research aims to analyse the population migration flows in European Union interrelating them with economic factors and statistically extrapolating the current trends to the perspective. The $\mathrm{EU}$ will be grouped 
into the labor-exporting and labor-receiving EU countries highlighting their economic differences and population changes. The official statistical data of Eurostat and The World Bank was used in this research.

The scientific problem is related to the benefits and disadvantages of international migration what is analysed in literature review of this research. The labor-exporting and labor-receiving countries publish accurate records on the number of international migrants that they produce and attract (Adams and Page 2005). However, the direction of migration flows has the crucial impact on countries' economies what the policy makers must consider promoting the economic growth. The lost of human capital can be observed in depopulating and developing countries when the educated workforce migrates to developed countries because a large fraction of the educated workforce is unemployed there. Since educated workers become one of the scarcest resources in developing countries slowing their development due to a 'brain drain' phenomenon (Fan and Stark 2007). Chen, Kosec, and Mueller (2019) suggested that the decision to migrate and understanding of well-being is time-varying rather than fixed. The inhabitants experiencing adverse economic shock may be more susceptible to emigration. However, observing the long-term economic differences between countries international migrants consider more stable changes in well-being associated with migration.

\section{Literature Review}

International migration is one of the most common demographic events in open economies. Sometimes a significant percentage of the particular country's population moves to another countries. The inhabitants can change the country of settlement several times during their life in pursuit of work, business, education opportunities, family creation, improved residential location, or retirement (Otoiu 2014). The classic economic model of the migration decision making suggests that persons analyse the costs of international migration with the value of the income earned in the destination country. Moving from a developing to a developed country is typical way for low-income people to increase their wages and improve their living conditions (Gibson et al. 2019). The most migrants from developing countries inside the $\mathrm{EU}$ are the economic migrants evaluating the economic push and pull factors and hoping that migration will provide them a better economic position to take care of their families (Gamso and Yuldashev 2018). Especially the macroeconomic shocks in developing countries are very important factors of emigration including 
short-term effects on income and consumption volatility when the households in developing countries are not capable to ensure the satisfactory consumption over economic fluctuations (Mendola 2017).

The international migration of economic migrants has the benefits and disadvantages for the destination countries as well as for the countries of origin. In the standard partial equilibrium labour market model, the growth of immigrant labour supply reduces the native-born employment, average labour costs and increases the profit of businesses (Hatton 2014). Badaoui, Strobl, and Walsh (2017) using the data from the United Kingdom suggest, that while migrants and natives are imperfect substitutes, migrants are close substitutes for other migrants, so that an increase in the stock of migrants lowers the wages of existing migrants but has little impact on natives. Often the immigrants are offered only low-skilled tasks with relatively lower wages, even in case when highly-skilled workers migrate (Dequiedt and Zenou 2013). For destination country's economics the immigration tends to be beneficial by stimulating the performance of the private sector through reduction of costs and induced manufacturing and trade (Egger, Erhardt, and Lassmann 2019).

In the countries of origin, the individuals who expect to migrate are less likely to invest in their native location of residence (Creighton 2013). But the remittances have a significant impact on the development of the countries of migrants' origin, as they are the most stable source of currency, a potential source of savings and future investment for capital formation and development (Ciuciu 2018). The remittances stimulate economics from emigrants reducing the recipient households' levels of poverty and increasing the domestic consumption. However, the decline of labourforce supply effect can be intensified through the refusion of remittances gaining households to participate in domestic labour market (Oldekop et al. 2018). Additionally, Murodova (2018) maintains that the economic behaviour of recipient households usually tends to increase the prices of goods and services in the local domestic market, potentially affecting the entire community, including non-recipient households. Even the international financial aid flows do not reduce emigration in the low and lowermiddle income countries. Usually measures that promote development in open economies tend to be associated with higher emigration (Lanati and Thiele 2018).

Waite and Smith (2017) characterized the positive 'win-win-win' outcomes of international migration for the individual migrant and organisations in places of origin and destination. This includes the mutual shar- 
ing and learning of good practices to enhance the working processes, cultures and performances. Fassio, Montobbio and Venturini (2019) investigated the impact of high skilled migration on innovation activities and proved it generally positive explained by two reasons. Firstly, skilled migration increases total invention through the direct contributions of immigrant inventors. And secondly, some evidence suggests that enterprises having the internationally diverse workforce tend to be more innovative. Due to transnationalism many migrants in different countries build their social networks that cross geographic, cultural, and political borders. Those cross-border structures often are defined not exclusively on networks, but they also materialize on other social forms including working groups and organizations (Bilecen, Gamper, and Lubbers 2018). Considering interpersonal relations, the international migrants must solve problems related to geographical barriers, herewith maintaining close ties with their family and friends left in their native countries. At the same time, they face the challenge of developing new interpersonal ties in a new cultural context (Lu, Hamamura, and Chan 2017).

International migration is a world-wide phenomenon with implications at economic, social, psychological, individual and collective levels. Among the multiple changes appeared as a result of international migration, is identified even the change of mentality of the immigrants. Commonly the mentality is defined as the most profound cultural element of the community members which is the most durable and the most resistant to changes. But the migration phenomenon affects the mentality changes as a result of particular social influences and of the cultural environment pressure, which are interiorized in mentalities of individuals, changing their judgment and evaluation criterions, and social actions patterns (Cormos 2014).

According to Stancu and Popescu (2018) migration is one of the consequences of globalization, alongside production internationalization, the new global division of labour, the new competitive environment, the state internationalization and the markets globalization. Boghean (2016) in addition to the neoclassical economic theory, which argues that external migration of population is mainly caused by economical differences, highlights the migration transition theory, which is related to a possibility of the temporarily migration to appear through the discovery of 'inflated migration.' An increase in wealth leads to an increase of the migration phenomenon. In most cases the developed countries attracting and keeping highly qualified immigrants have the beneficial alternative to the 
decrease of local aging workforce. The sending countries that lack the employment opportunities on the labour market may suffer from 'brain drain' (Collier, Piracha, and Randazzo 2018). So, the return of migrants to their country of origin and the development of efficient return measures have become more prominent on the political agenda of many European countries (Lietaert, Broekaert, and Derluyn 2017). According to Issifou and Magris (2017) the return migration involves two main positive impacts on the countries of origin. The emigrants bring earned financial resources to their domestic economies as they have accumulated savings while working abroad. Using these savings, the returnees are engaged in business activities. As emigrants also have gained new skills and increased their human capital from their foreign residence, they can successfully realize their abilities in the domestic countries usually having a wage premium for their international experience.

Piras (2017) found that human capital is expected to have opposite effects in the sending and the receiving economies. The international migration is expected to be higher, when the mean level of education in the source country is higher and lower when the mean level of education in the destination country is higher. The 'brain drain' is highly related to the international migration of graduated youth which seeks to improve expected future real income streams and employment opportunities. In effect, migration allows an individual to realize higher returns to the human capital over the lifetime and improve the consumption opportunities (Dotzel 2017). The loss of young people is a long-standing demographic phenomenon in less economically developed and non-metropolitan areas of many industrialised countries. Affected by declines in labour force opportunities driven by technological change and increased mechanisation, non-metropolitan communities have historically experienced outmigration of young individuals to urban centres where they pursue education, employment opportunities and a more vibrant social environment (Rowe, Corcoran, and Bell 2017). The international migration motivated by work and employment tend to occur more often in early adulthood when individuals' careers are forming. Choices concerning work, residential mobility and early labour market experiences at this stage have lasting consequences for individuals' subsequent work and life outcomes (Perales 2017). On the policy side, different regions have become increasingly aware of the importance of highly educated individuals for their local economic growth and, thus, have implemented policies that allow them to compete more fiercely to attract and retain them. It is very well 
known in regional science that the most educated individuals are also the most internally and internationally mobile tending to relocate multiple times during their lifetimes (Faggian, Rajbhandari, and Dotzel 2017). So, in global economy the international migration is typical phenomenon prompting countries to compete for the high-skilled workforce.

Migration events are directly related to the short-term future uncertainty. The benefits and disadvantages of staying in the country of origin are obvious, but the full benefits of emigration cannot be known in advance, and this ambiguity can be considered as an additional cost. Uncertainty is, furthermore, a subjective cost, because different persons can evaluate it very differently. But the economic and social costs of migration process in most cases are being evaluated and predicted by the potential international economic migrants. The direction of migration flows is directly related to these costs and benefits (Campbell 2019).

\section{Research Methodology}

In the beginning of the research the $\mathrm{EU}$ migration statistics will be analysed, and the average annual population change rates will be calculated. Using the migration index the $\mathrm{EU}$ countries will be grouped into two groups: having the positive and negative net migration flows. The natural increment will be also analysed as the demographic factor of population changes. The crude rate of natural increase and migration index matrix will aggregate the analysis results highlighting the factors of population changes in EU-28 countries.

Secondly, the economic factors of international migration directions in the $\mathrm{EU}$ will be analysed. To compare the differences of economic development in the EU-28 as the main international migration factor the dimension index will be calculated of these macroeconomic indicators: GDP per capita, average labour cost per hour worked, labour productivity percentage of $\mathrm{EU}$ average, compensation of employees per capita, consumption expenditures of households per capita, and gross capital formation (investments) per capita. The economic differences will be interrelated with the international migration flows. The EU assessment will also be analysed as the international migration promoting factor.

Finally, the statistical projections of $\mathrm{EU}$ population in the context of international migration will be extrapolated. The economic development projections of depopulating $\mathrm{EU}$ countries will be interrelated with the possibilities to reduce the emigration. The economic differences inside the depopulating $\mathrm{EU}$ counties will be highlighted. The statistical trends 
of net international migration in immigrants attracting and high emigration $\mathrm{EU}$ countries will be given considering the impact of non-EU immigrants on the EU migration statistics. The statistical probabilities to reduce the emigration in most depopulating $\mathrm{EU}$ countries will be estimated using the mean-variance method.

The official statistical international migration, demographic, and economic data of Eurostat and The World Bank will be used in the research. The statistical data analysis (dynamic statistics and derivative demographic indicators, dimension index, regression, Spearman correlation, Wilcoxon's test, mean-variance) and visualization (contour and other charts) methods will be employed in the empirical research.

\section{Differences of Population Migration Flows and Natural Increment in European Union}

During the last decade (2008-2017) the world population increased by $11.3 \%$ from 6.766 to 7.530 billion inhabitants. The population of European Union (EU-28) at the same period grew by $2.1 \%$ and at the end of 2017 reached 512.7 million inhabitants. However, the population changes in the EU have different directions: in 18 countries the population growth was observed (Luxembourg, Malta, Cyprus, Sweden, Ireland, United Kingdom, Belgium, Austria, Denmark, France, Netherlands, Finland, Italy, Slovenia, Czechia, Spain, Slovakia, and Germany) while in the rest 10 countries (Lithuania, Latvia, Bulgaria, Romania, Croatia, Greece, Hungary, Portugal, Estonia, and Poland) the population was declining. The average annual population changes of every EU country are shown in figure 1. The highest depopulation is typical for Lithuania and Latvia ($1.33 \%$ and $-1.29 \%$ yearly), whereas the rest 8 countries lose in average from $0.63 \%$ (Bulgaria) to $0.04 \%$ (Poland) of their population.

The comparative immigration and emigration flow indicators are given in figure 2. The outstanding average annual gross migration (emigration and immigration) was in Germany (1.121 million migrants yearly). Another four EU-28 countries having the highest migration flows were United Kingdom (911.7 thousand), Spain (808.8 thousand), France (595.9 thousand), and Italy (491.2 thousand). In 2008-2017 the migration index (proportion of immigrants to emigrants) of all EU-28 countries that had positive population change indicators (\%) was equal or higher than 1 (in range from 1.0 to 3.7), what means that almost in all cases the immigration to these countries exceeds the emigration flows. Otherwise, in the group of countries having the negative average annual population change 


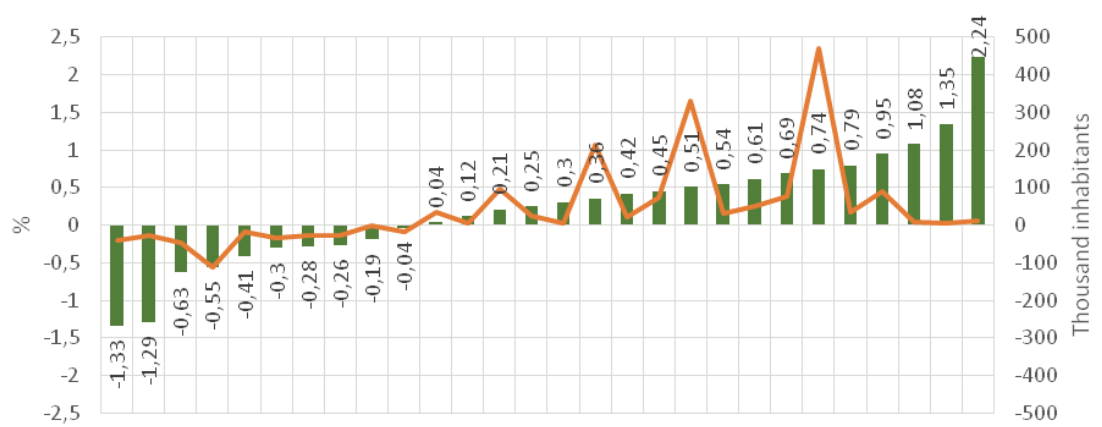

LT LV BGROHR EL HU PT EE PL DE SK ES CZ SI IT FI NL FR DKAT BE UK IE SE CYMTLU

Average annual change (\%) Average annual change (thousand inhabitants)

FIG URE 1 Average Annual Population Change of EU-28 Countries in 2008-2017 (based on data from Eurostat, https://ec.europa.eu/eurostat)

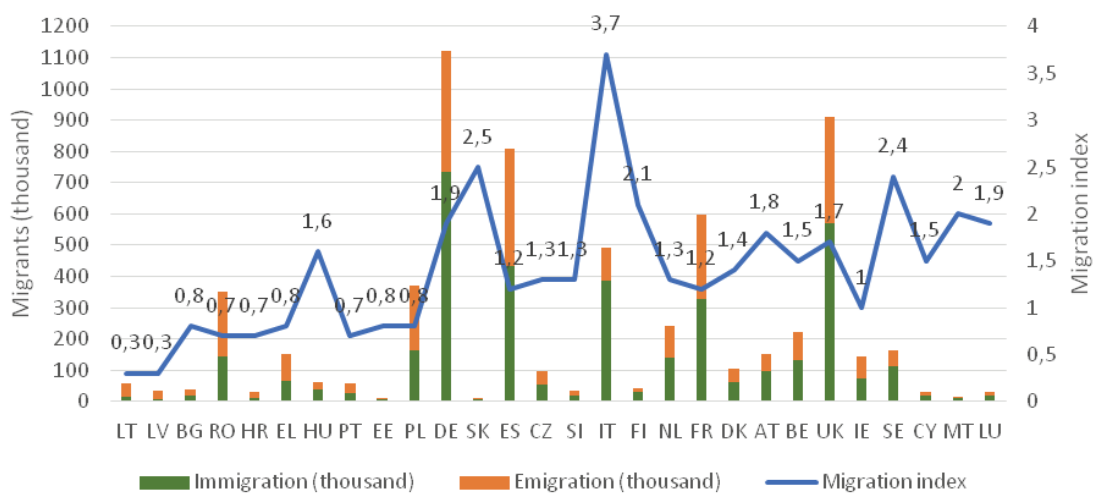

FIGURE 2 Average Annual Immigration, Emigration and Migration Index of EU-28 countries in 2008-2017 (based on data from Eurostat, https://ec.europa.eu/eurostat)

rates (\%) the migration index is lower than 1 in all cases except Hungary which in average had 160 immigrants relatively to 100 emigrants. The worst situation was in Lithuania and Latvia where only 30 immigrants formed positive migration flow relatively to 100 emigrants. It is evident that such huge negative net migration causes the rapid depopulation of these two E $\mathrm{U}$ countries. In the rest $7 \mathrm{EU}$ countries (Bulgaria, Romania, Croatia, Greece, Portugal, Estonia, and Poland) the migration index is quite stable in range from 0.7 to 0.8 (figure 2).

The second factor of population change during the period is natural increment. Having the population change and net migration indicators 


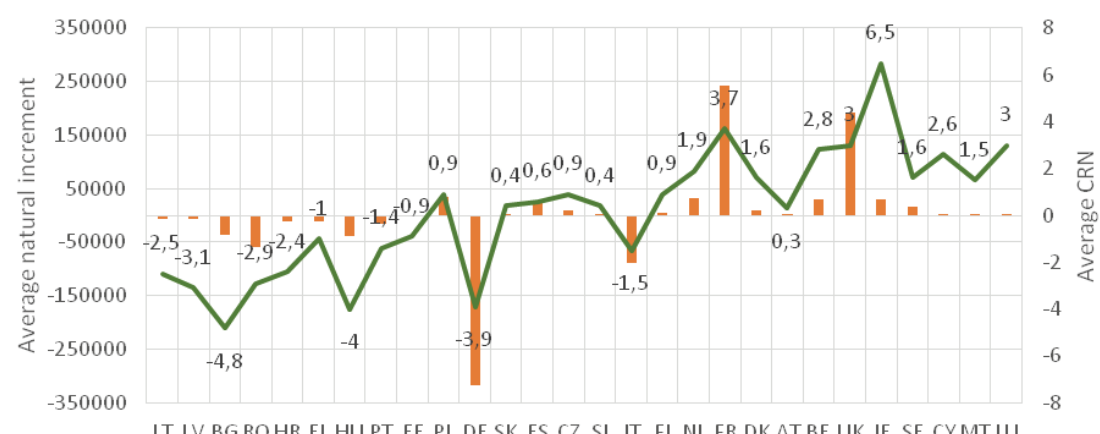

IT LV BG ROHR EL HU PT EE PL DE SK ES CZ SI IT FI NL FR DK ATBE UK IE SE CYMTLU

Average natural increment of population (B - D) — Average CRN

FIgURE 3 Average Natural Increment of Population and CRN of EU-28 Countries in 2008-2017 (based on data from Eurostat, https://ec.europa.eu/eurostat)

the natural increment of EU-28 countries' population was calculated by formula:

$$
(B-D)=\left(P_{1}-P_{\mathrm{o}}\right)-(I-E),
$$

where $(B-D)$ is natural increment of population (births minus deaths), $\left(P_{1}-P_{\mathrm{o}}\right)$ is the net change in population during the period, $(I-E)$ is the mechanical increase/decrease (net migration) of population (immigration minus emigration).

To highlight the problems of negative natural increment in EU-28 countries the average crude rate of natural increase (CRN) was calculated for the period of 2008-2017:

$$
\mathrm{CRN}=\frac{B-D}{P} \times 1000,
$$

where $B$ is births, $D$ is deaths, and $P$ is population of a country. This relative ratio shows the natural increment to 1000 inhabitants and allows compare the $\mathrm{EU}$ countries that have the significant differences of total population.

The analysis results have shown that only two EU-28 countries (Germany and Italy) have negative natural increment in the group of 18 countries with growing population (figure 3 ). The population growth in these countries is based only on positive net migration flows, while another 16 $\mathrm{EU}$ countries ensure their population growth by natural increment and positive net migration of inhabitants. Conversely, from ten EU countries with declining population for nine the negative natural increment is typi- 
TABLE 1 Matrix of EU-28 Countries' Population Change, Migration Index and CRN

\begin{tabular}{lll}
\hline $\mathrm{CRN}$ & \multicolumn{2}{c}{ Migration index } \\
\cline { 2 - 3 } & $\mathrm{MI}<1$ & $\mathrm{MI} \geq 1$ \\
\hline $\mathrm{CRN}<\mathrm{O}$ & $\mathrm{LT}^{(-)}, \mathrm{LV}^{(-)}, \mathrm{BG}^{(-)}, \mathrm{RO}^{(-)}, \mathrm{HR}^{(-)}, \mathrm{EL}^{(-)}, \mathrm{HU}^{(-)}, \mathrm{DE}^{(+)}, \mathrm{IT}^{(+)}$ \\
& $\mathrm{PT}^{(-)}, \mathrm{EE}^{(-)}$ & \\
\hline $\mathrm{CRN} \geq \mathrm{O}$ & $\mathrm{PL}^{(-)}$ & $\mathrm{SK}^{(+)}, \mathrm{ES}^{(+)}, \mathrm{CZ}^{(+)}, \mathrm{SI}^{(+)}, \mathrm{FI}^{(+)}, \mathrm{NL}^{(+)}$, \\
& & $\mathrm{FR}^{(+)}, \mathrm{DK}^{(+)}, \mathrm{AT}^{(+)}, \mathrm{BE}^{(+)}, \mathrm{UK}^{(+)}$, \\
& & $\mathrm{IE}^{(+)}, \mathrm{SE}^{(+)}, \mathrm{CY}^{(+)}, \mathrm{MT}^{(+)}, \mathrm{LU}^{(+)}$ \\
\hline
\end{tabular}

NOTES ${ }^{(+)}$Population of country is growing, ${ }^{(-)}$population of country is declining.

cal, except Poland which has the CRN of 0.9. The worst fertility situation is in Bulgaria and Hungary that have CRNS of -4.8 and -4.0 accordingly. The CRN of other countries with declining population (Lithuania, Latvia, Romania, Croatia, Greece, Portugal, and Estonia) vary from -0.9 to -3.1.

Three analysed indicators (population change, migration index and crude rate of natural increase) were summarized in matrix that divides the EU-28 countries into four groups (table 1). The bottom right cell includes 16 from 18 countries where population is growing. All these countries have positive net migration flows and natural population increase rates. Two countries (Germany and Italy) have positive net migration but their natural increment is negative. However, the immigration exceeds the negative natural increment, so the population in these countries is growing. Hungary belongs to the same top right cell of matrix, but the negative natural increment is not compensated by immigration, so the population in this country declines. Only Poland is located at the bottom left cell of matrix which has positive natural increment of population but negative net migration flows. As the emigration exceeds the positive natural increment, the population of Poland is slightly declining (in average by $0.04 \%$ yearly). Finally, the top left cell of matrix includes 8 countries (Lithuania, Latvia, Bulgaria, Romania, Croatia, Greece, Portugal, and Estonia) where the population is constantly declining, the natural increment of inhabitants is negative, and the emigration from these countries is higher than immigration. This group of $\mathrm{EU}-28$ countries meets the demographic and depopulation problems in the converse context of $\mathrm{EU}$ and world's population growth trends.

Analyzing the population migration changes over time the Migration Effectiveness Ratios (MER) were calculated for EU countries in 20072016: 


$$
\operatorname{MER}=\frac{I-E}{I+E},
$$

where $I$ is immigration and $E$ is emigration. MER is defined as the ratio of net migration to gross migration (migration turnover). This ratio measures the relative difference between the effective addition or loss of population through migration and the overall gross movement. For the open economies the circular migration or repeat migration is typical which is the temporary and usually repetitive movement of a migrant worker between home and host areas, usually for the purpose of employment. The MER is able highlight the attractiveness or unattractiveness of a country for international migrants and represents the established pattern of population mobility.

The EU countries were classified into three groups according to MER. The average values of MER in 2007-2016 are given in the brackets:

- Group 1 (MER > o): Italy (0.55), Slovakia (o.43), Sweden (0.40), Finland (0.36), Luxembourg (0.30), Hungary (0.30), Malta (0.28), Austria (0.27), United Kingdom (0.25), Belgium (0.20), Denmark (0.17), Netherlands (0.14), and France (0.10).

- Group 2 (MER is varying): Germany (o.29), Cyprus (0.25), Slovenia (o.11), Czechia (0.09), Spain (0.04), Ireland (0.01), Greece (-0.08), Portugal (-0.10), Estonia (-0.14), and Croatia (-0.15).

- Group 3 (MER < o): Latvia (-0.50), Lithuania (-0.48), Poland ($0.17)$, Romania (-0.16), and Bulgaria (-0.07).

The countries of Group 1 are constantly attracting immigrants while the countries of Group 3 are losing the population every year. The countries in Group 2 have various (positive and negative) MER values in different years. The countries having the significantly changing trends of MER are shown in figure 4.

The most significant positive MER growth was observed in Austria and Malta. Poland has constantly reduced the negative MER from -0.41 to -0.06 . This means that these three countries in period of 2007-2016 became more attractive for immigrants. Otherwise, the most declining $M E R$ during the same period was in $6 \mathrm{EU}$ countries. In Italy and Hungary after significant decline the MER remained positive. The MER values of Greece, Cyprus, and Portugal became negative however in 2015-2016 they started to grow. The constant MER decline was in Croatia where this rate from 0.24 in 2007 declined to -0.45 in 2016.

The next chapter aims to reveal the economic differences of coun- 

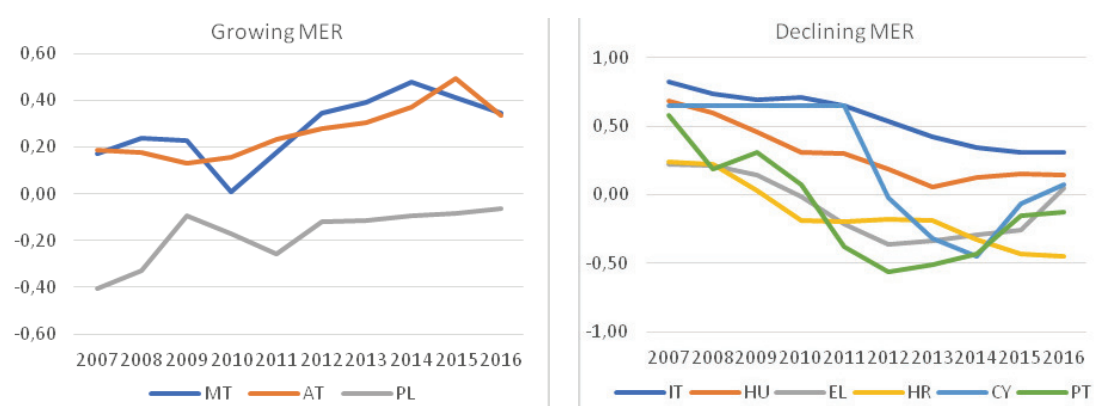

FIGURE 4 EU Countries with the Most Significant Changes of MER

tries having the negative migration flows to the countries attracting immigrants. The obtained migration openness factor when these countries joined the $\mathrm{EU}$ will be also considered seeking to evaluate how the membership in the $\mathrm{EU}$ shrinks the population of less developed $\mathrm{EU}$ countries.

\section{Economic Factors of Migration Directions in the EU}

Undoubtedly, the main international migrants in the $\mathrm{EU}$ are the economic migrants and the differences of countries' economic development can be considered as main factors attracting immigrants or stimulating emigration. To highlight the economic inequalities inside the $\mathrm{EU}$ and interrelate them with the migration flows the gross domestic product (GDP) per capita and average 1 hour labour cost were analysed. The values of these economic indicators in every $\mathrm{EU}$ country having the negative net migration $(\mathrm{MI}<1)$ were compared to the averages of $\mathrm{EU}-28$ and the $\mathrm{EU}$ countries having the positive net migration flows $(M I \geq 1)$. The average GDP per capita in MI < 1 group was 13689 EURO in 2017. In overall $\mathrm{EU}-28$ this indicator was higher by $119.2 \%$ (30 OOO EURO), while the EU countries attracting immigrants had the average value higher by $166.4 \%$ (36 474 EURO). The least migration index (o.3) in period of 2008-2017 was in Lithuania and Latvia where the relative emigration was the highest in the EU, however the GDP per capita of these countries are not the least. The lower indicators are in Bulgaria, Romania, Croatia, and Poland (figure 5).

The average labour cost per hour in $\mathrm{MI}<1$ countries was $9.7 \mathrm{EURO}$, while the EU-28 and MI $\geq 1$ averages were 26.8 and $27.1 \mathrm{EURO}$ accordingly. So, the employees working in $\mathrm{MI}<1$ countries earn in average only $35.8 \%$ of income compared to other $\mathrm{EU}$ countries that attract immigrants. According to this indicator Lithuania and Latvia $(\mathrm{MI}=0.3)$ have higher 

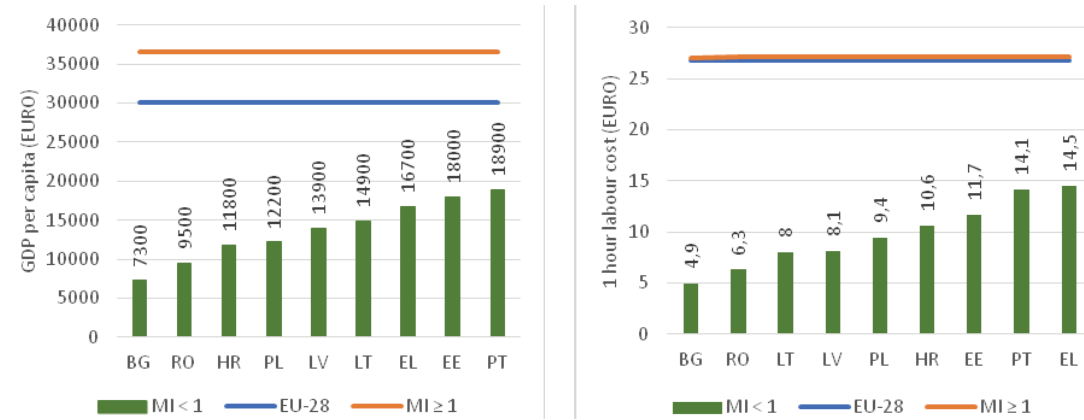

FIGURE 5 GDP per Capita and 1 Hour Labour Cost of $\mathrm{MI}<1$, EU-28 and $\mathrm{MI} \geq 1$ Countries in 2017 (based on data from Eurostat, https://ec.europa.eu/eurostat)

wages compared to Bulgaria and Romania where the negative migration balance is not so huge ( $\mathrm{MI}$ is 0.8 and 0.7 ).

To compare the differences of economic development as the main international migration factor the dimension index $\left(D_{i}\right)$ was calculated of 6 macroeconomic indicators (year 2017) for every EU-28 country: GDP per capita (GDP), average labour cost per hour worked ( $\mathrm{LCH}$ ), labour productivity percentage of EU average (LPP), compensation of employees per capita (COE), consumption expenditures of households per capita (CEH), and gross capital formation (investments) per capita (GCF):

$$
D_{i} \frac{X_{i}-X_{\min }}{X_{\max }-X_{\min }},
$$

where $X_{i}$ is the value of country's macroeconomic indicator, $X_{\min }$ is the minimal value and $X_{\max }$ is the maximal value of macroeconomic indicator in the $\mathrm{EU}-28$. The dimension index creates the scale in range of $[0 ; 1]$ to relatively compare the economic differences in the $\mathrm{EU}$. The sum of 6 dimension indices was calculated for every country which allows quantitatively measure the position of a country in the context of EU-28. The range of dimension index sum is $[0 ; 6]$ where o means the least and 6 means the highest relative economic development of the $\mathrm{EU}$ countries.

The $9 \mathrm{EU}$ countries of MI $<1$ group (Lithuania, Latvia, Bulgaria, Romania, Croatia, Greece, Portugal, Estonia, and Poland) are located between 12 countries having the least sums of dimension indices with values of 1.16 and less (figure 6). Three countries also have relatively low macroeconomic indicators (Hungary, Slovakia, and Czechia) but their international migration balance is positive ( $\mathrm{MI}>1$ ). The huge emigration paradox of Lithuania and Latvia can be seen in figure 6 even though their eco- 


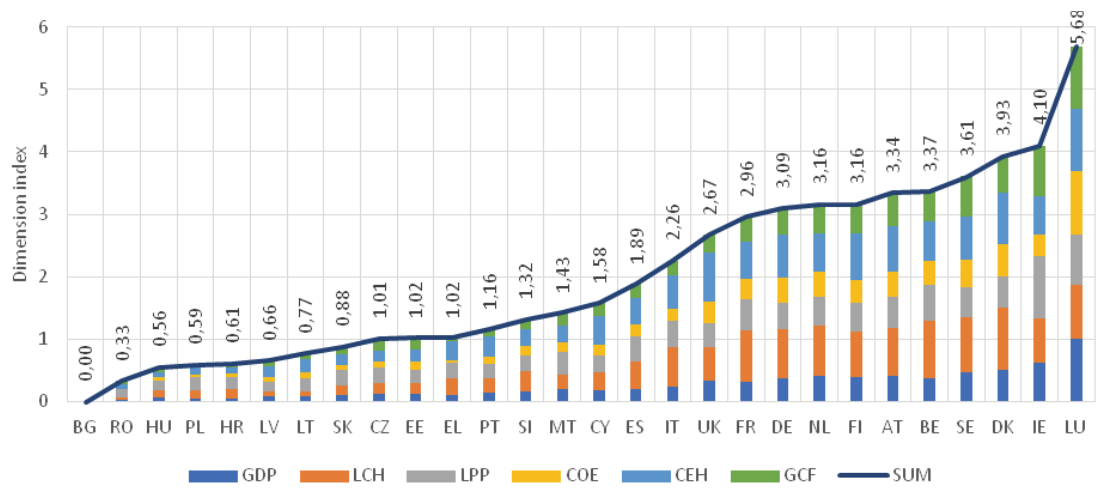

FIGURE 6 Dimension Index of E U-28 Countries' 6 Macroeconomic Indicators in 2017 (based on data from Eurostat, https://ec.europa.eu/eurostat)

nomic indicators are not the worst (22nd and 23rd ranks in the EU-28). As the emigrants of these countries are economic migrants, that can be hypothetically explained by higher expectations of life quality of Lithuanian and Latvian inhabitants compared to Bulgaria, Romania, Hungary, Poland, and Croatia. All 6 analysed macroeconomic indicators are the least in Bulgaria (the sum of dimension indices is equal to o). The countries having positive net migration flows ( $\mathrm{MI} \geq 1$ ), except Hungary, Slovakia, and Czechia, obtained the sums of dimension indices from 1.32 (Slovenia) to 5.68 (Luxembourg).

The contour charts visualize the statistical dependencies between country's economic development and the directions of international migrant flows (figure 7$)$. The negative net migration balance $(\mathrm{MI}<1)$ is typical only for EU countries having the least investments and GDP per capita values. Conversely, the more developed EU countries attract international migrants $(\mathrm{MI} \geq 1$ ). The outstanding (top right corner of $\mathrm{MI}$ $\geq 1$ graph in figure 6) GDP per capita (more than 50 thousand EURO) and gross capital formation per capita (more than 10 thousand EURO) indicators have Luxembourg, Ireland, and Denmark.

So, in general the interrelation of country's economic development and the direction of its migration flows is evident. The openness of a country is also very important factor allowing the international migrants easily change the location of residence. The $9 \mathrm{EU}$ countries having the negative net migration flows $(\mathrm{MI}<1)$ accessed the $\mathrm{EU}$ in different years: Greece (1981), Portugal (1986), Lithuania (2004), Latvia (2004), Estonia (2004), Poland (2004), Bulgaria (2007), Romania (2007), and Croatia 

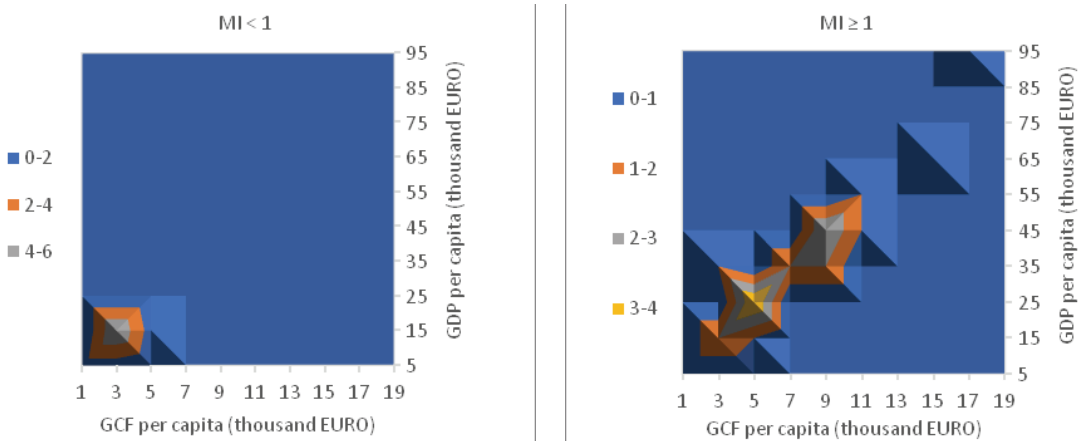

FIGURE 7 Distribution of $\mathrm{MI}<1$ and $\mathrm{MI} \geq 1$ Countries According to GDP and Gross Capital Formation (GCF) per Capita in 2017 (based on data from Eurostat, https://ec.europa.eu/eurostat)

(2013). From 9 countries having the negative net migration flows 6 were selected considering these criterions (Lithuania, Latvia, Estonia, Poland, Bulgaria, and Romania):

- The EU accession year is between 1998-2018 (the last 20 years).

- The sum of calculated economic indicators' dimension indices is lower than $20 \%$ of maximal possible value of $6\left(\sum D_{i}<1.2\right)$.

- The country is EU member for 10 years and more.

The aggregated population of these 6 countries was calculated 10 years before and after EU assessment (figure 8) where the conditional year 'zero' means the country's EU assessment year. The aggregated average annual population decline rates were also calculated before and after $\mathrm{EU}$ assessment. The analysis results have shown that in general the country's EU assessment does not increase the value of population decline rate. The average population decrease in 6 analysed countries before $\mathrm{EU}$ assessment was $-0.44 \%$ yearly while after these countries became the $\mathrm{EU}$ members the decrease rate turned to $-0.34 \%$ per year. However, the population decline was reduced only in Estonia, Poland, Bulgaria, and Romania. The depopulation of Lithuania and Latvia after EU assessment increased 1.8 and 1.2 times accordingly (figure 8).

The slowdown of depopulation decrease in most countries after EU assessment can be explained by growing economy and improved living conditions. To highlight the economic growth effect of countries after the EU assessment the GDP per person employed (constant 2011 PPP USD) was compared calculating the average values of 10 years before and after the countries became the EU members (table 2). GDP per person em- 

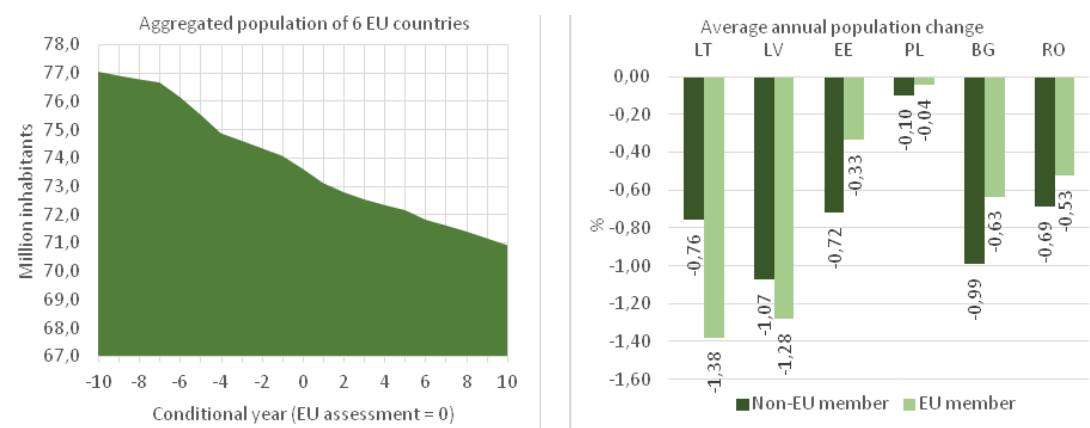

Figure 8 Aggregated Population and Average Annual Population Change of 6 E U Countries 10 Years before and after EU Assessment (based on data from The World Bank, https://www.worldbank.org)

TABLE 2 GDP per Person Employed (Constant 2011 PPP USD)

\begin{tabular}{lrrrrrrr}
\hline Item & LT & LV & EE & PL & B G & RO \\
\hline $\begin{array}{l}\text { Non-E U member (10 years } \\
\text { average) }\end{array}$ & 28711 & 26030 & 33528 & 35083 & 27712 & 27043 \\
E U member (10 years average) & 51580 & 44820 & 53332 & 50107 & 38771 & 45367 \\
Difference $\left(d_{i}\right)$ & 22869 & 18790 & 19805 & 15024 & 11059 & 18324 \\
Rank & 1 & 3 & 2 & 5 & 6 & 4 \\
\hline
\end{tabular}

nOTES based on data from The World Bank (https://www.worldbank.org).

ployed is gross domestic product divided by total employment in the economy. Purchasing power parity (PPP) GDP is GDP converted to 2011 constant international dollars using P P P rates. An international dollar has the same purchasing power over GDP that a Us dollar has in the United States. The highest GDP per person employed indicator after the $\mathrm{EU}$ assessment was in Estonia, however the most significant increase was observed in Lithuania (rank is equal to 1). Latvia was the third country considering the GDP growth. The less impact of country's EU assessment on GDP growth was in Romania, Poland, and Bulgaria (ranks 4-6 accordingly).

Using the data of table 2 the Wilcoxon's test was performed to prove the positive impact on countries' economic growth when they become members of $\mathrm{EU}$. The sums of attributed ranks for negative and positive differences are: $t_{-}=\mathrm{O}$ and $t_{+}=21$. The statistical hypotheses of the analysis are: the EU membership does not improve ( $\mathrm{HO}$ ) and improve ( $\mathrm{H} 1)$ the country's GDP per person employed indicator. The hypothesis Ho was 

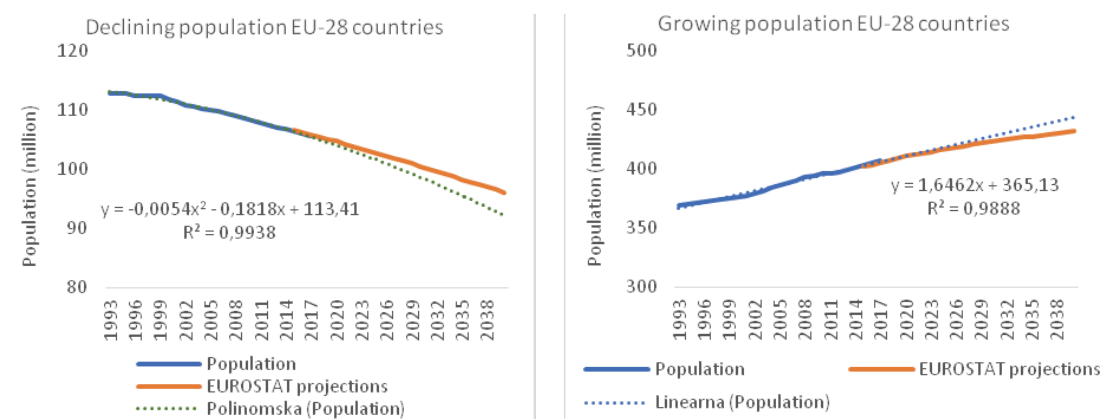

FIgure 9 Statistical Projections Until 2040 of EU-27 and UK Population (based on data from Eurostat, https://ec.europa.eu/eurostat)

rejected because $t_{-}$value was considered as low according to Wilcoxon's test for one set of observations $(n=6 ; p=0.05)$.

The analysis results allow maintain that economic differences of the $\mathrm{EU}$ countries have the crucial impact on the migration directions of $\mathrm{EU}$ inhabitants. In most cases the less economically developed countries' E U assessment does not increase its population decline rate. Conversely, the depopulation slowdown effect was observed as a benefit of significant economic growth. However, this is not typical for Lithuania and Latvia, that have not the least macroeconomic indicators in the $\mathrm{EU}-28$, their economic growth after the $\mathrm{EU}$ assessment was one of the highest, but these two countries face the problem of the most rapid depopulation compared to other $8 \mathrm{Eu}$ countries (Bulgaria, Romania, Croatia, Greece, Hungary, Portugal, Estonia, and Poland) with declining population.

\section{Statistical Projections of EU Population in the Context of International Migration}

The statistical prediction models of polynomial and linear regression were developed to foresee the possible aggregated population changes until 2040 in declining (Lithuania, Latvia, Bulgaria, Romania, Croatia, Greece, Hungary, Portugal, Estonia, and Poland) and growing population (according to figure 1 data) groups of current E U-28 countries. These statistical predictions were also compared to the official $\mathrm{E} U$ population projections of Eurostat. The statistical models were developed using the 25 years EU population data of 1993-2017 (figure 9).

Predicting the EU population by the polynomial and linear regression models the independent variable $x$ must be considered as the time characteristics where $1993=1$. The statistical modelling allows maintain that 
in the group of countries with declining population the aggregated number of inhabitants should decrease by $12.8 \%$ from 105.7 million in 2017 to 92.2 million in 2040. This group of EU countries is expected to lose 13.5 million inhabitants in next 22 years. The official population projections of Eurostat are more optimistic: this group of countries until 2040 will has lost $9.1 \%$ or 9.6 million inhabitants. Predictions of linear regression model show that the rest $17 \mathrm{EU}$ countries and United Kingdom together will increase their population by $9.2 \%$ (37.3 million) from 406.8 million in 2017 to 444.1 million inhabitants in 2040. The official projections of Eurostat for the second group are more restrained: 432.2 million inhabitants in 2040 (the expected growth is $6.2 \%$ ). The overall population of EU-27 and $\mathrm{UK}$ in 2040 should be 528.4 million inhabitants or 536.3 million inhabitants according to statistical modelling of this research. The difference between the official and estimated predictions is 7.9 million inhabitants (1.5\%).

In table 3 the statistical linear regression models were developed to estimate the linear trends of $\mathrm{MI}<1$ countries' (negative net migration) GDP and gross capital formation (GCF) per capita statistical indicators. Considering that economic differences between the $\mathrm{EU}$ countries are the factor of economic migrants' international migration the statistical modelling allows foresee when these economic indicators of MI $<1$ countries could reach the 2017 year's levels of $\mathrm{MI} \geq 1$ and overall EU-28 averages under the circumstances that the average annual growth rates $(\mathrm{G}(\%))$ remain the same. The possible equalization of macroeconomic indicators could reduce the emigration from $\mathrm{MI}<1$ countries. The coefficients of determination $\left(R^{2}\right)$ in table 3 indicate the strength of statistical interdependencies between macroeconomic rates and time characteristics $(t)$ in the statistical models.

The statistical data of 2006-2017 period was used developing the GDP per capita regression models. The conditional time characteristic $t$ is equal to 1 at year 2006 except Greece where the period of 2014-2017 was analysed. The GDP per capita of this country since 2008 (21 800 EURO) was declining until 2014 (16 400 EURO). As the developed regression models aim to extrapolate the growing trend of GDP, the conditional time characteristic $t$ in the model of Greece is equal to 1 at year 2014. Equalizing the linear regression models of GDP per capita growth in each country to the EU-28 (30 OOO EURO) and MI $\geq 1$ countries' ( 36474 EURO) averages of 2017 the years $(t)$ were determined when the countries of MI < 1 group could reach the values of selected datum-levels (figure 10). Having the av- 
TABLE 3 GDP and GCF per Capita Statistical Growth Models of MI < 1 Countries

\begin{tabular}{|c|c|c|c|c|c|c|}
\hline & \multicolumn{3}{|c|}{ GDP per capita } & \multicolumn{3}{|c|}{ GCF per capita } \\
\hline & $G$ & Statistical model & $R^{2}$ & $G$ & Statistical model & $R^{2}$ \\
\hline LT & 6.6 & $\mathrm{GDP}=598.6 \cdot t+7042.4$ & 0.91 & 8.2 & $\mathrm{GCF}=171.85 \cdot t+1314.6$ & 0.98 \\
\hline LV & $5 \cdot 4$ & $\mathrm{GDP}=425.52 \cdot t+8009.1$ & 0.70 & 4.9 & $\mathrm{GCF}=121.6 \cdot t+1850.2$ & 0.63 \\
\hline B G & 6.9 & $\mathrm{GDP}=287.41 \cdot t+3631.8$ & 0.95 & $2.1^{*}$ & $\mathrm{GCF}=24.071 \cdot t+1190.7$ & 0.65 \\
\hline RO & 6.8 & $\mathrm{GDP}=325.52 \cdot t+4909.1$ & 0.81 & 4.1 & $\mathrm{GCF}=65.579 \cdot t+1511.9$ & 0.92 \\
\hline HR & 2.2 & $\mathrm{GDP}=104.9 \cdot t+9868.2$ & 0.36 & $3 \cdot 4^{*}$ & $\mathrm{GCF}=75.095 \cdot t+1862.5$ & 0.75 \\
\hline EL & $0.6^{*}$ & $\mathrm{GDP}=90 \cdot t+16250$ & 0.60 & $1.9^{*}$ & $\mathrm{GCF}=38.589 \cdot t+1874.3$ & 0.32 \\
\hline $\mathrm{PT}$ & 1.6 & $\mathrm{GDP}=168.88 \cdot t+15811$ & 0.49 & $4 \cdot 3^{*}$ & $\mathrm{GCF}=123.45 \cdot t+2248.7$ & 0.77 \\
\hline $\mathrm{EE}$ & $5 \cdot 5$ & $\mathrm{GDP}=647.9 \cdot t+9263.6$ & 0.87 & $7 \cdot 7$ & $\mathrm{GCF}=216.5 \cdot t+2439.8$ & 0.71 \\
\hline PL & 4.9 & $\mathrm{GDP}=376.57 \cdot t+7393.9$ & 0.90 & 2.5 & $\mathrm{GCF}=39.588 \cdot t+1843.3$ & 0.56 \\
\hline
\end{tabular}

NOTES ${ }^{*}$ Different period of statistical data compared to other countries.

erage annual GDP per capita growth rate of 5.4\%-6.6\% Estonia, Lithuania and Latvia could reach the EU-28 average of 2017 in years 2038-2058. To reach the average value ( $36474 \mathrm{EURO}$ ) of immigrants attracting countries $(\mathrm{MI} \geq 1)$ the time period until $2048-2073$ is necessary for these three Baltic states. The slowest GDP per capita growth rate (o.6\%-2.2\%) is typical for Greece, Portugal, and Croatia (table 3). The GDP per capita value of Portugal was the highest between the MI $<1$ countries (18 900 EURO in 2017) so its relatively slow growth does not elongate the time period to reach the EU-28 and MI $\geq 1$ averages as in Croatia and Greece. Having the relatively slow GDP per capita growth rate Croatia could reach the EU-28 average in 2198 , while the value at the average of immigrants attracting countries can be expected only in 2260. The expected years of Greece are 2167 and 2239 accordingly (figure 10).

As the investments are the main factor of GDP growth, the statistical extrapolation using the data of 2009-2017 was implemented for gross capital formation (GCF) per capita indicators (table 3 and figure 10). The linear regression models of Bulgaria, Croatia, and Portugal were developed using the statistical data of 2012-2017, while the analysis period of Greece includes the years 2013-2017. This shortening of data periods was implemented due to the necessity reveal the statistical investments growth trend. In 2008-2011 the investments of these countries declined: $-28.3 \%$ in Bulgaria, $-32.4 \%$ in Croatia, and $-20.4 \%$ in Portugal. The worst situation was in Greece where the real business investments declined by 

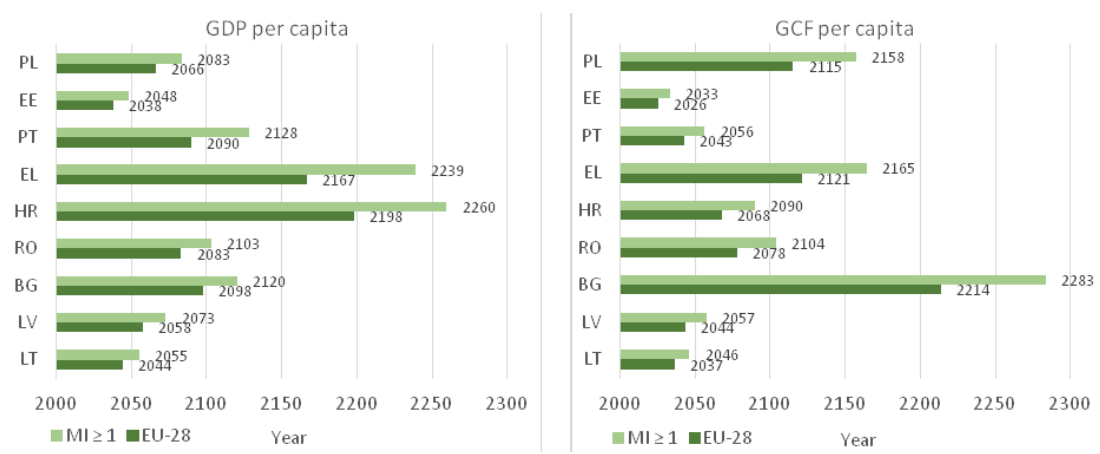

FIGURE 10 Years of MI $<1$ Countries Statistically Expected to Reach the GDP and GCF per Capita Average Values of 2017 in MI $\geq 1$ and EU-28 Groups

65.3\% (from 5472 to 1899 E URO per capita) during the period of 20072014.

The Baltic states have the most rapid investments growth trend. The GCF per capita in Lithuania grew by $8.2 \%$, in Estonia by $7.7 \%$, and in Latvia by $4.9 \%$ yearly during the period of 2009-2017. So, these countries statistically can expect to reach the current EU-28 average in 2026-2044. The average of MI $\geq 1$ countries can be reached in 2033-2057. The slowest GCF per capita growth was observed in Greece (1.9\%), Bulgaria (2.1\%), and Poland (2.5\%). These countries having the same statistical trend can expect to reach the average of $\mathrm{EU}-28$ in $2115-2214$, while the average of immigrants attracting countries $(M I \geq 1)$ can be reached in 2158-2283.

Analysing the group of 9 countries having the negative net migration flows $(\mathrm{MI}<1)$ the Spearman correlation coefficients $(\rho)$ were calculated for the ranks of countries' annual population change rates to GDP and GCF per capita:

$$
\rho=1-\frac{6 \cdot \sum d^{2}}{n^{3}-n}
$$

where $d$ is the difference of ranks between country's average annual population change rate and GDP/GCF per capita, $n$ is the number of countries analysed. The ranks (relatively 1 is the best and 9 is the worst value of statistical indicators) necessary for the calculation of Spearman correlation coefficients are given in table 4.

The Spearman correlation coefficients $\rho \mathrm{GDP}=0.37$ and $\rho \mathrm{GCF}=0.22$ allow maintain that there is not strong direct statistical relation between population decline rates and analysed two macroeconomic indicators inside the group of $\mathrm{MI}<1$ countries. Lithuania and Latvia meet the huge 
TA B LE 4 Ranks and $d^{2}$ Values of Demographic and Economic Indicators inside $\mathrm{MI}<1$ Group

\begin{tabular}{lrrrrrrrrr}
\hline Country & PL & EE & P T & EL & HR & RO & BG & LV & LT \\
\hline Population change rank & 1 & 2 & 3 & 4 & 5 & 6 & 7 & 8 & 9 \\
GDP rank and $d^{2}$ & $6 / 25$ & $2 / 0$ & $1 / 4$ & $3 / 1$ & $7 / 4$ & $8 / 4$ & $9 / 4$ & $5 / 9$ & $4 / 25$ \\
GCF rank and $d^{2}$ & $6 / 25$ & $1 / 1$ & $2 / 1$ & $7 / 9$ & $5 / 0$ & $8 / 4$ & $9 / 4$ & $3 / 25$ & $4 / 25$ \\
\hline
\end{tabular}
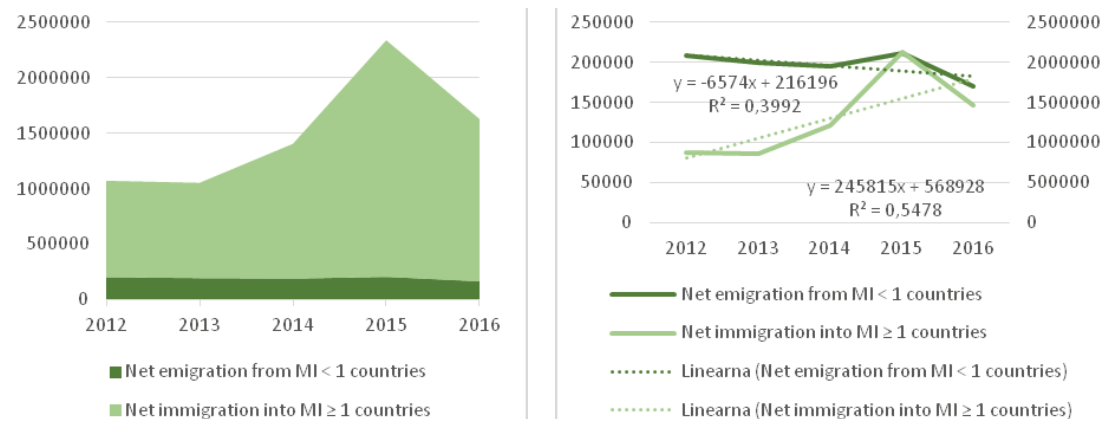

FIGURE 11 Statistical Trends of Net Migration Flows in MI $<1$ and MI $\geq 1$ Countries

depopulation problems having relatively high economic indicators. The estimated direct statistical relation is in Portugal and Estonia that have the highest GDP and GCF per capita values (ranks 1 and 2) so these countries face with quite low population decline rates. Conversely Poland has the 6th ranks of macroeconomic indicators but its depopulation problem is the least (population declines only -0.04\% per year).

The analysis of international migration statistical trends has shown that in recent years the net emigration from $\mathrm{MI}<1$ countries is slightly declining in average by $5 \%$ yearly (figure 11). In 2012 in this group of countries net emigration was 208052 persons while in 2016 this number decreased to 169428 . Conversely, the net immigration to MI $\geq 1$ countries is growing in average by $13.9 \%$ every year. The significant decline was observed only in 2016 when this indicator from 2129656 persons in 2015 decreased to 1461584 . The gap in figure 11 between net emigration from $\mathrm{MI}<1$ countries and immigration to $\mathrm{MI} \geq 1$ countries indicates the magnitude of immigration from non-EU countries into the $\mathrm{E} U$. In period of 2012-2016 the average difference between mentioned rates is 1109898 what is the non-EU immigrants.

As Lithuania and Latvia are the EU countries that mostly suffer from emigration problem the mean-variance method was applied to estimate 
TABLE 5 Mean-Variance Analysis of Lithuanian and Latvian Emigration

\begin{tabular}{lcrrrrr}
\hline$C$ & $P_{(\mathrm{LT})}$ & $P_{(\mathrm{Lv})}$ & $\mathrm{CP}_{(\mathrm{LT})}$ & $\mathrm{CP}_{(\mathrm{LV})}$ & $(C-\mathrm{EMV})^{2} P_{(\mathrm{LT})}$ & $(C-\mathrm{EMV})^{2} P_{(\mathrm{LV})}$ \\
\hline 20 & 0.00 & 0.58 & 0.00 & 11.67 & 0.00000 & 19.84954 \\
30 & 0.25 & 0.25 & 7.50 & 7.50 & 50.17361 & 4.340278 \\
40 & 0.42 & 0.17 & 16.67 & 6.67 & 7.233796 & 33.44907 \\
50 & 0.17 & 0.00 & 8.33 & 0.00 & 5.671296 & 0.00000 \\
60 & 0.08 & 0.00 & 5.00 & 0.00 & 20.8912 & 0.00000 \\
70 & 0.00 & 0.00 & 0.00 & 0.00 & 0.0000 & 0.00000 \\
80 & 0.08 & 0.00 & 6.67 & 0.00 & 107.0023 & 0.00000 \\
& - & - & 44.17 & 25.83 & 190.9722 & 57.63889 \\
\hline
\end{tabular}

the statistical probabilities of emigration reduction considering the current emigration trends of 2005-2016.

In table ${ }_{5} C$ is the middle of emigrants' interval (thousand persons) after the grouping of statistical data, $P$ is the distribution of years according to emigration values, and $\mathrm{CP}$ is the product of previously mentioned indicators. The weighted averages (EMV), standard deviations ( $\rho$ ) and standardized values $(z)$ of emigrants were calculated using the data of table 5 :

$$
\begin{aligned}
\text { EMV } & =\sum C_{i} P_{i} \\
\sigma & =\sqrt{\sum\left(C_{i}-\mathrm{EMV}\right)^{2} P_{i}} \\
z & =\frac{\left(C_{i}-\mathrm{EMV}\right)}{\sigma}
\end{aligned}
$$

Using the table of standard normal distribution, the $\Phi(-u)$ values were found for the standardized emigration indicators $u=|z|$. The probability graphs of Lithuanian and Latvian emigration reduction expectancies are given in figure 12 .

The statistical data of 2005-2016 shows that from Lithuania in average emigrate 44444 and from Latvia 24398 inhabitants every year. The current statistical trends and mean-variance analysis allow affirm that the possibility significantly reduce the emigration in these countries is very doubtful. The statistical probability to reduce the emigration in Lithuania even by $10 \%$ is $63.67 \%$ in Latvia is $67.98 \%$. If wanting the significant decline of emigration in these countries by $50 \%$ Lithuania has the statistical probability of $12.47 \%$, Latvia $9.66 \%$. So, the huge emigration paradox in Lithuania and Latvia is more related to the economic differences between these countries and highly developed EU countries rather than 

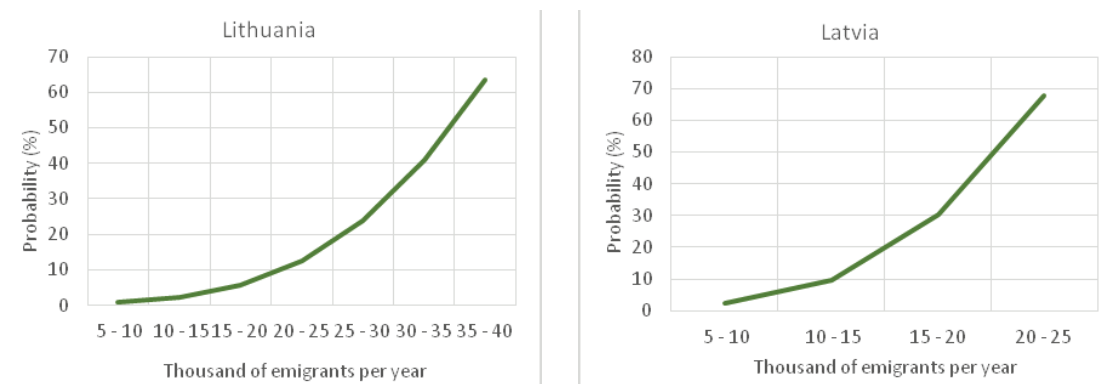

FIGURE 12 Probabilities of Emigration Reduction in Mostly Depopulating EU Countries

the relative economic differences inside the group of $\mathrm{MI}<1$ countries. The gap of economic indicators between highly developed E U countries and Lithuania as well as Latvia allows expect the continuity of labor force supply from these countries.

\section{Conclusions}

The research has shown that in current years $10 \mathrm{EU}$ countries meet the problem of population decline while in 18 countries the population is growing. In all $\mathrm{EU}$ countries with growing population the migration index is equal or higher than 1 , what means that almost in all cases the immigration is higher than the emigration flows. Otherwise, in the group of countries having the declining population the migration index is lower than 1 in all cases except Hungary. Only Germany and Italy have negative natural increment in the group of 18 countries with growing population. The population growth in these countries is based only on positive net international migration flows, while another $16 \mathrm{EU}$ countries ensure their population growth by natural increment and positive net migration of inhabitants. Conversely, from ten EU countries with declining population for nine the negative natural increment is typical, except Poland.

Analysing the economic factors of international migration, it was concluded that $9 \mathrm{EU}$ countries of having the negative net migration flows (Lithuania, Latvia, Bulgaria, Romania, Croatia, Greece, Portugal, Estonia, and Poland) are located between 12 countries having the least macroeconomic indicators. Three countries also have relatively low macroeconomic indicators (Hungary, Slovakia, and Czechia) but their international migration balance is positive. The negative net migration balance is typical only for EU countries having the least investments and GDP per capita values. The economic differences of the $\mathrm{EU}$ countries have the cru- 
cial impact on the migration directions of $\mathrm{EU}$ inhabitants. In general, the country's EU assessment does not increase the value of population decline rate. The slowdown of depopulation decrease in most countries after EU assessment can be explained by growing economy and improved living conditions. However, this is not typical for Lithuania and Latvia, that have not the least macroeconomic indicators in the $\mathrm{EU}-28$, their economic growth after the $\mathrm{EU}$ assessment was one of the highest, but these two countries face the problem of the most rapid depopulation.

The statistical modelling allows maintain that in the group of countries with declining population the aggregated number of inhabitants should decrease by $12.8 \%$ from 105.7 million in 2017 to 92.2 million in 2040. This group of $\mathrm{EU}$ countries is expected to lose 13.5 million inhabitants in next 22 years. Predictions of linear regression model show that the rest $17 \mathrm{EU}$ countries and United Kingdom together will increase their population by $9.2 \%$ ( 37.3 million) from 406.8 million in 2017 to 444.1 million inhabitants in 2040. The analysis results allow maintain that there is not strong direct statistical relation between population decline rates and analysed macroeconomic indicators inside the group of countries with negative net migration flows. Lithuania and Latvia meet the huge depopulation problems having relatively high economic indicators what is more related to the economic differences between these countries and highly developed EU countries rather than the relative economic differences inside the group of countries with negative net migration directions. Lithuanian and Latvian emigration paradox allows expect the continuity of labor force supply from these countries to EU constantly shrinking the domestic labor markets.

\section{References}

Adams, R. H. Jr., and J. Page. 2005. 'Do International Migration and Remittances Reduce Poverty in Developing Countries?' World Development 33 (10): 1645-69.

Badaoui, E., E. Strobl, and F. Walsh. 2017. 'Impact of Internal Migration on Labor Market Outcomes of Native Males in Thailand.' Economic Development \% Cultural Change 66 (1): 147-77.

Bilecen, B., M. Gamper, and M. J. Lubbers. 2018. 'The Missing Link: Social Network Analysis in Migration and Transnationalism.' Social Networks 53: $1-3$.

Boghean, C. 2016. 'The Phenomenon of Migration: Opportunities and Challenges.' The USV Annals of Economics and Public Administration 16 (3): 14-20. 
Campbell, P. 2019. 'Dispositional Traits and Internal Migration: Personality as a Predictor of Migration in Australia.' Journal of Research in Personality 78 (1): 262-67.

Chen, J., K, Kosec, and V. Mueller. 2019. 'Moving to Despair? Migration and Well-Being in Pakistan.' World Development 113:186-203.

Ciuciu (Portan), M. M. 2018. 'Advantages and Disadvantages of Labor Migration.' The Annals of the University of Oradea: Economic Sciences 27:38-46.

Collier, W., M. Piracha, and T. Randazzo. 2018. 'Remittances and Return Migration.' Review of Development Economics 22 (1): 174-202.

Cormos, V. C. 2014. 'Mentality and Change in the Context of International Migration.' Procedia: Social and Behavioral Sciences 149: 242-47.

Creighton, M. J. 2013. 'The Role of Aspirations in Domestic and International Migration.' The Social Science Journal 50 (1): 79-88.

Dequiedt, V., and Y. Zenou. 2013. 'International Migration, Imperfect Information, and Brain Drain.' Journal of Development Economics 102:6278.

Dotzel, K. R. 2017. 'Do Natural Amenities Influence Undergraduate Student Migration Decisions?' Annals of Regional Science 59 (3): 677-705.

Egger, P. H., K. Erhardt, and A. Lassmann. 2019. 'Immigration and Firms' Integration in International Production Networks.' European Economic Review 111:1-34.

Faggian, A., I. Rajbhandari, and K. R. Dotzel. 2017. 'The Interregional Migration of Human Capital and Its Regional Consequences: A Review.' Regional Studies 51 (1): 128-43.

Fan, C. S., and O. Stark. 2007. 'International Migration and "Educated Unemployment"'. Journal of Development Economics 83 (1): 76-87.

Fassio, C., F. Montobbio, and A. Venturini. 2019. 'Skilled Migration and Innovation in European Industries.' Research Policy 48 (3): 706-18.

Foged, M. 2016. 'Family Migration and Relative Earnings Potentials.' Labour Economics 42:87-100.

Gamso, J., and F. Yuldashev. 2018. 'Does Rural Development Aid Reduce International Migration?' World Development 110:268-82.

Gibson, J., D. McKenzie, H. Rohorua, and S. Stillman. 2019. 'The LongTerm Impact of International Migration on Economic Decision-Making: Evidence from a Migration Lottery and Lab-in-the-Field Experiments.' Journal of Development Economics 138:99-115.

Hatton, T. J. 2014. 'The Economics of International Migration: A Short History of the Debate.' Labour Economics 30:43-50.

Issifou, I., and F. Magris. 2017. 'Migration Outflows and Optimal Migration Policy: Rules versus Discretion.' Portuguese Economic Journal 16 (2): 87-112. 
Lanati, M., and R. Thiele. 2018. 'The Impact of Foreign Aid on Migration Revisited.' World Development 111:59-74.

Lietaert, I., E. Broekaert, and I. Derluyn. 2017. 'From Social Instrument to Migration Management Tool: Assisted Voluntary Return Programmes: The Case of Belgium.' Social Policy \% Administration 51 (7): 961-80.

Lu, M., T. Hamamura, and Y. P. Chan. 2017. 'International Migration and Social Pain Responses.' Personality and Individual Differences 109:13741.

Mendola, M. 2017. 'International Migration and Informal Social Protection in Rural Mozambique.' Research in Economics 71 (2): 282-90.

Murodova, S. 2018. 'Impact of Remittances and International Migration on Poverty in Central Asia: The Cases of the Kyrgyz Republic, Tajikistan, and Uzbekistan.' Journal of Applied Economics and Business Research 8 (1): $38-56$.

Oldekop, J. A., K. R. E. Sims, M. J. Whittingham, and A. Agrawal. 2018. 'An Upside to Globalization: International Outmigration Drives Reforestation in Nepal.' Global Environmental Change 52:66-74.

Otoiu, A. 2014. 'Getting Your Migration Analysis Together by Integrating Internal and International Migration.' Procedia: Social and Behavioral Sciences 149:685-90.

Perales, F. 2017. 'Dynamics of Job Satisfaction around Internal Migrations: A Panel Analysis of Young People in Britain and Australia.' Annals of Regional Science 59 (3): 577-601.

Piras, R. 2017. 'A Long-Run Analysis of Push and Pull Factors of Internal Migration in Italy: Estimation of a Gravity Model with Human Capital Using Homogeneous and Heterogeneous Approaches.' Papers in Regional Science 96 (3): 571-603.

Rowe, F., J. Corcoran, and M. Bell. 2017. 'The Returns to Migration and Human Capital Accumulation Pathways: Non-Metropolitan Youth in the School-to-Work Transition.' Annals of Regional Science 59 (3): 81945.

Stancu, S., and O. M. Popescu. 2018. 'International Migration: The Analysis of Economic Impact in the Globalization Context.' Economic Computation and Economic Cybernetics Studies and Research 52 (4): 79-94.

Waite, C. A., and D. P. Smith. 2017. 'Temporary Skilled International Migration of Young Professional Cricketers: "Going Down-Under" to MoveUp the Career Path.' Geoforum 84:70-76. 